\title{
Modelo de avaliação da estratégia ambiental: estudos no setor têxtil $^{1}$
}

\author{
Environmental Strategic Evaluation Model: Textile Sector Studies
}

\author{
Mônica Cavalcanti Sá de Abreu' \\ Sandra Maria dos Santos ${ }^{2}$ \\ Gregório Jean Varvakis Rados ${ }^{3}$
}

\section{Resumo}

O trabalho apresenta a aplicação, no setor têxtil, do modelo de avaliação da estratégia ambiental, denominado ECPAmbiental (Estrutura-Conduta-Performance). A concepção do modelo ECP-Ambiental tem, como princípio básico, que a performance ambiental de uma empresa é o reflexo de suas práticas competitivas ou padrões de conduta ambiental, que, por sua vez, dependem da estrutura de mercado em que está inserida. A pesquisa ao setor têxtil foi realizada no ano de 2001, em empresas instaladas nos estados do Ceará e Santa Catarina, através de entrevistas diretas aos representantes das empresas da amostra selecionada. O trabalho apresenta uma ferramenta de tomada de decisão que posiciona estrategicamente as empresas em função da conduta ambiental adotada e da pressão da estrutura da indústria. A pesquisa revela a existência de três perfis de conduta ambiental, denominados de conduta fraca, intermediária e forte. Os resultados indicam que a legislação ambiental, o risco ambiental e as exigências ambientais das partes interessadas exercem uma baixa pressão ambiental sobre a estrutura da indústria têxtil. Foram, também, identificados os indicadores usados pelas empresas têxteis para a avaliação do seu desempenho ambiental. Os resultados comprovam a utilização do modelo ECP-Ambiental como uma ferramenta consistente e prática para desenvolver e integrar estratégias empresariais em um ambiente de mercado globalizado e competitivo.

Palavras chave: Gestão Ambiental, performance ambiental, indicadores ambientais, estratégia ambiental.

\section{Abstract}

This paper presents the Environmental Strategic Evaluation Model (Environmental-SCP), applied to the Textile Sector. The Environmental-SCP Model works on the assumption that the environmental performance of a company is the result of its competitive practices or environmental conduct standards, depending on the structure of the market in which it is inserted. The data were collected through interviews with the Environmental Managers of companies located in Ceara and Santa Catarina in the year of 2001. This work presents a decision-making tool that helps companies position themselves strategically depending on their environmental behavior and market structure constraint. The results show three environmental behaviors classified as strong, medium and weak. The research also shows that the environmental risk, the environmental legal system, and the demands from stakeholders represent a low environmental constraint on the structure of the textile industry. The indicators which are utilized by the textile companies to assess their environmental performance were also identified. The results present this model as a consistent and practical tool to develop and evaluate business strategies in a global competitive market place.

Key words: Environmental Management, Environmental Performance, Environmental Indicators, Environmental Strategic

\footnotetext{
* Artigo expandido em relação ao apresentado no VII ENGEMA - Encontro Nacional sobre Gestão Empresarial e Meio Ambiente, São Paulo, 10 a 12 de novembro de 2003.

1 Doutora em Engenharia de Produção Universidade Federal deSanta Catarina, Mestre em Tecnologia de Processos Bioquímicos (Escola de Química/Universidade Federal do Rio de Janeiro), Engenheira Química (Universidade Federal do Ceará). Professora Adjunta da Faculdade de Economia, Administração, Atuárias e Contabilidade (FEAAC/UFC). Endereço: Rua Vicente de Castro Filho, nº1550 - Luciano Cavalcante - Fortaleza/Ceará - CEP: 60813540 - Brasil - E-mail: mabreu@ufc.br

${ }^{2}$ Pós Doutorado em Economia (UFPE), Doutorado em Economia (UFPE), Mestrado em Economia (CAEN/UFC), graduação em Ciências Econômicas. Professora Adjunta da Faculdade de Economia, Administração, Atuárias e Contabilidade (FEAAC/UFC)

Endereço: Rua Barão de Aratanha, nº 836/806B - Bairro: Fátima - Fortaleza/Ceará - CEP: 60050070 - Brasil -E-mail: smsantos@ufc.br

3 Doctor in Manufacturing Engineering. - Loughborough University, Leics, Inglaterra; Mestrado em Engenharia de Produção (UFSC), Engenheiro Mecânico (UFRGS). Professor Adjunto, Centro de Ciências da Educação, Departamento de Biblioteconomia e Documentação - Universidade Federal de Santa Catarina. Endereço: Rua Liberato Caroni, nº250 - Lagoa da Conceição. Florianópolis/Santa Catarina - CEP: 88062205 - Brasil - grego@deps.ufsc.br

Artigo submetido em dezembro de 2006 e aceito em janeiro de 2007
} 


\section{Introdução}

De acordo com a Análise Setorial da Gazeta Mercantil (1999, v.I), a indústria têxtil mundial tem passado por um intenso processo de transformação. Nas décadas de 80 e de 90 , novos países emergiram como grandes exportadores de produtos têxteis, destacando-se os asiáticos, como a Coréia do Sul e Taiwan, acirrando a concorrência e dando maior amplitude ao fenômeno da globalização.

Paralelamente, os países industrializados, tentando salvaguardar suas indústrias têxteis, agiram basicamente, em duas linhas: estabeleceram barreiras, tarifárias e não tarifárias, e implementaram políticas industriais e tecnológicas ativas. Essas políticas buscavam aumentar a produtividade, como forma de atenuar as vantagens comparativas proporcionadas pelos baixos salários vigentes nos países em desenvolvimento. A modernização do processo produtivo resultou no aumento da exigência por qualificação e na utilização de novos modelos de gestão.

Para enfrentar essa nova realidade mundial, as empresas brasileiras do setor têxtil estão se reestruturando investindo em maquinário moderno, em administração profissional, em novos nichos de mercado, no desenvolvimento de estratégias de marketing e na formação de joint ventures. Fusões de empresas do setor têm ocorrido nos últimos anos, com muitas empresas de pequeno e médio porte, formando unidades de tamanho econômico.

Dentro da estratégia de recuperação da competitividade, está ocorrendo o deslocamento regional, com a transferência de fábricas para a região Nordeste e para o norte de Minas Gerais, em virtude de incentivos fiscais e menores custos com a mão-de-obra. Além dos incentivos fiscais, alguns governos estaduais têm participado junto com as empresas, no desenvolvimento de programas de qualificação e de treinamento de mão-de-obra e na criação de cooperativas de trabalhadores, que atuam como 'subcontratados' das indústrias (Banco do Nordeste, 1999).

Um fator determinante para a competitividade das empresas é a qualidade final do tecido produzido. As empresas vêm investindo em programas de gestão da qualidade e produtividade, em capacitação de recursos humanos e na adequação tecnológica. As empresas brasileiras que exportam para os países da Europa estão implantando Sistemas de Gestão Ambiental, certificados pela NBR ISO 14001, e desenvolvendo produtos com selo verde. Os produtos têxteis podem ser certificados com o 'Ôkotex', que dá garantia de que não contêm substâncias nocivas ao ser humano e ao meio ambiente (GAZETA MERCANTIL, 1999, V.III).

Esse cenário, em que as empresas têxteis estão competindo, exige uma profunda reestruturação na conduta e uma nova maneira de estabelecer a estratégia a ser adotada, para se manterem competitivas. Paralelamente, Elkington e Trisoglio (1996) afirmam que o conceito de 'sustentabilidade' vem tomando parte das principais correntes de discussão política, e as mudanças, entretanto, trazem consigo uma enorme complexidade em termos econômicos, tecnológicos, sociais e ambientais. Os autores consideram, entretanto, que as ferramentas para analisar e modelar a tomada de decisão e o embasamento teórico dos framework estão inadequadas ao conceito de 'sustentabilidade'.

Os modelos ambientais, atuais, (Responsible Care; NBR ISO 14001; NORCIA, 1996; ELKINGTON, 1998, RODRIGUEZ; RICART, 1998) conferem apenas certificados de conformidade, sem que haja um ordenamento contínuo da performance ambiental entre os diversos classificados. Dessa forma, não possibilitam inferir, sistematicamente, comportamentos ou condutas ambientais mais efetivas em relação a outras empresas submetidas à certificação.

Portanto, a necessidade de um modelo teórico de análise estrutural, que levasse em conta a variável ambiental na definição da estratégia empresarial, resultou na concepção do modelo de avaliação da estratégia ambiental, denominado de ECP-Ambiental (Estrutura-Conduta-Performance). O modelo ECP-Ambiental, desenvolvido por Abreu (2001), permite inferir que a performance ambiental de uma 
empresa é o reflexo de suas práticas competitivas ou padrões de conduta ambiental, os quais, por sua vez, dependem da estrutura de mercado em que a empresa está inserida.

Este trabalho se propõe aplicar o modelo ECP-Ambiental em empresas têxteis, instaladas no Ceará e em Santa Catarina. A pesquisa de campo foi conduzida em 2001 e oferece um quadro organizado das pressões ambientais, ditadas por meio da legislação ambiental, do risco ambiental e das exigências ambientais das partes interessadas. $O$ trabalho também identifica a conduta ambiental frente aos indicadores, definidos no modelo ECP-Ambiental, e, os indicadores de performance ambiental, utilizados pelas empresas pesquisadas, concluindo com o posicionamento estratégico das empresas têxteis.

Além desta introdução e das considerações finais, o artigo está estruturado em seções. A seção 2 discute a dimensão ambiental do modelo ECP-Ambiental e apresenta a hipótese a ser testada. A metodologia é discutida na seção 3. A seção 4 apresenta os resultados da pesquisa e está dividida em três subseções: a primeira contém a estrutura da indústria têxtil e suas características ambientais, a segunda expõe a conduta ambiental adotada e a terceira identifica os indicadores de performance ambiental. A seção 5 realiza a avaliação estratégica ambiental das empresas têxteis com base na matriz de posicionamento estratégico ambiental.

\section{Entendendo o Modelo de Avaliação da Estratégia Ambiental}

Um dos modelos mais conhecidos para a análise da vantagem competitiva fundamenta-se nas idéias de Edward Mason e Joe Bain sobre a estrutura da indústria e é chamado de SCP Paradigm (Struture-ConductPerformance) ou Estrutura-Conduta-Desempenho (ECD). O paradigma SCP, conforme Scherer e Ross (1990), estabelece que a performance econômica de uma empresa é o resultado de uma série de condutas adotadas pela mesma, a partir de decisões estratégicas e que, como conseqüência, determinam o seu posicionamento dentro da estrutura da indústria a qual pertence. Segundo esse modelo, a análise da estrutura da indústria é o ponto de partida para a definição das estratégias empresariais e o seu posicionamento dentro da estrutura é que vai determinar o seu sucesso ou fracasso no cenário competitivo.

Seguindo os fundamentos teóricos do paradigma SCP, o modelo ECP-Triplo desenvolvido por Abreu (2001), estabelece que uma empresa submetida a pressões da estrutura industrial busca uma performance tripla (econômica, ambiental e social) e, para tanto, adota condutas sociais e ambientais, além da econômica, em todas as suas funções gerenciais. O posicionamento estratégico da empresa dentro da estrutura da indústria, e, conseqüentemente, sua performance econômica, social e ambiental, serão definidos por sua conduta econômica, ambiental e social, traduzida no modelo de gestão adotado pela organização.

A dimensão ambiental foi desenvolvida em separado, no modelo ECP-Ambiental (figura 1). A relação de causalidade do paradigma SCP é mantida para efeito de estudo da aplicabilidade do modelo ECP-Ambiental. A utilidade do modelo ECP-Ambiental está relacionada com a compreensão da estrutura da indústria, determinada principalmente por condicionantes de oferta e de demanda, e das articulações que constituem as cadeias produtivas. O modelo é útil, do mesmo modo, no entendimento da conduta ambiental das empresas e da performance resultante. Aspectos dinâmicos ao modelo são percebidos quando da mudança de conduta ambiental das empresas participantes, com reflexos na performance ambiental e na estrutura de mercado. 
Figura 1. Modelo de Avaliação da Estratégia Ambiental - ECP-Ambiental.

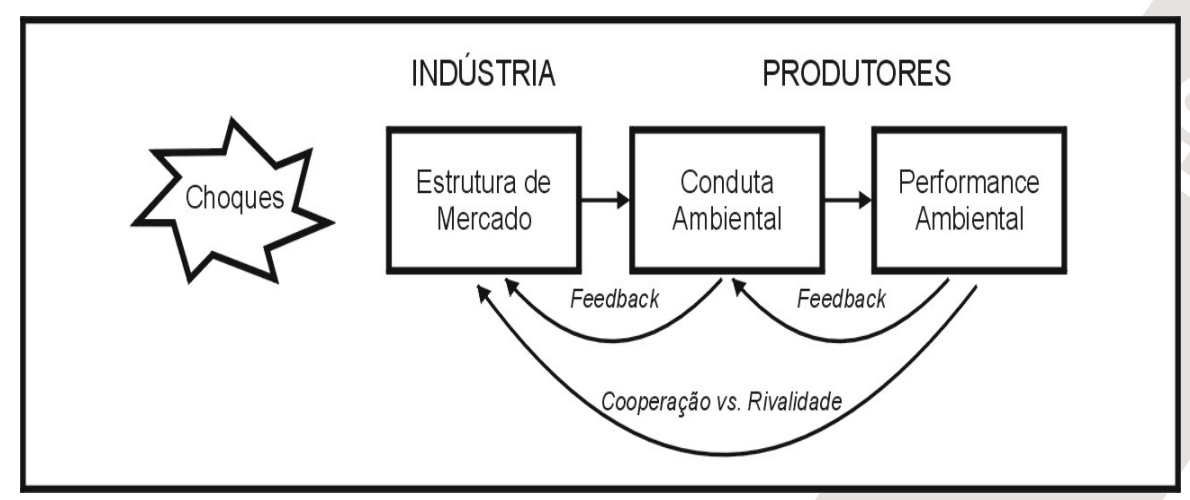

Fonte: Abreu (2001)

O Modelo PSR (Pressão-Estado-Resposta) (OECD, 1998) também foi utilizado para construir os conceitos de pressão da estrutura da indústria, conduta e performance ambientais. O modelo PSR adota o conceito de causalidade e considera que as atividades humanas exercem pressões no meio ambiente que afetam a qualidade e a quantidade dos recursos naturais (estado). A sociedade responde a essas mudanças, através de políticas públicas e setoriais e, de mudanças no seu comportamento. Rye e Celius (1997) aplicaram o modelo PSR na indústria de óleo e gás e propuseram uma adaptação no framework. As pressões significam, então, a integração entre as preocupações ambientais e as demandas das partes interessadas, os indicadores de resposta representam a integração entre as preocupações ambientais e as ações das firmas, e os indicadores de estado avaliam a performance ambiental da empresa.

Para entender o modelo ECP-Ambiental, observa-se que as empresas atuam em um sistema de mercado aberto sob a influência de eventos significativos, denominados de choques. Os choques conferem dinamismo ao modelo quando exigem respostas na estrutura e na conduta das empresas, com reflexos na performance ambiental. Elkington (1999) define os choques como forças externas em direção à sustentabilidade. O autor demonstra que as mudanças ocorrem, principalmente, devido à necessidade das empresas em satisfazer os direitos das comunidades e dos indivíduos sobre as ações que afetam diretamente a sua saúde, a segurança e o meio ambiente.

A pressão exercida pelas partes interessadas em comprovar a responsabilidade social, apresentada nos relatórios de desempenho das empresas; e por fim, devido à demanda da sociedade e dos governos por novas tecnologias para reduzir os níveis de emissões gasosas causadores do efeito estufa e para aumentar o uso dos recursos naturais nas empresas. Portanto, de acordo com o modelo ECP-Ambiental, os choques são basicamente oriundos da ação governamental com alterações na política e na legislação, das inovações tecnológicas e de mudanças no comportamento social.

É importante ressaltar ainda a existência de feedbacks internos e de uma relação de cooperação e rivalidade entre as empresas. Na concepção do Modelo ECP-Ambiental foi adotada a existência de feedbacks internos. De acordo com Porter (1980), a existência desses feedbacks confere dinamismo ao paradigma ECD. Em termos práticos, significa que uma mudança na conduta pode ter reflexos na estrutura com um possível aumento ou redução das barreiras de entrada para novos competidores.

Por outro lado, a rivalidade ocorre porque um ou mais concorrentes sentem-se pressionados ou percebem a oportunidade de melhorar sua posição. Segundo Porter (1980), na maioria das indústrias, os movimentos competitivos de uma firma têm efeitos notáveis em seus concorrentes e pode, assim, incitar à retaliação ou aos esforços para conter esses movimentos; ou seja, as empresas são mutuamente dependentes. Esse padrão de ação e reação pode, ou não, permitir que a empresa iniciante e a indústria como um todo se aprimorem. 
A cooperação convive com a rivalidade entre as empresas de uma indústria. Porter (1999) apresenta como exemplo de cooperação, a pesquisa cooperativa e os consórcios setoriais. A base dessa cooperação reside na crença de que a pesquisa independente, por parte dos rivais, é desperdício e duplicação. Dentro dessa perspectiva de $\mathrm{P} \& \mathrm{D}$, a redução do impacto ambiental dos produtos e processos se encaixa como uma forma de cooperação, porque eles permeiam entre vários setores e exigem substanciais investimentos.

Os indicadores do modelo ECP-Ambiental estão apresentados no quadro 1, onde é possível visualizar todos os elementos que compõem o modelo, desde os aspectos dinâmicos designados de choques externos, até os indicadores de estrutura de mercado, de conduta e de performance ambientais.

\section{Quadro 1. Framework dos Indicadores do Modelo ECP-Ambiental.}

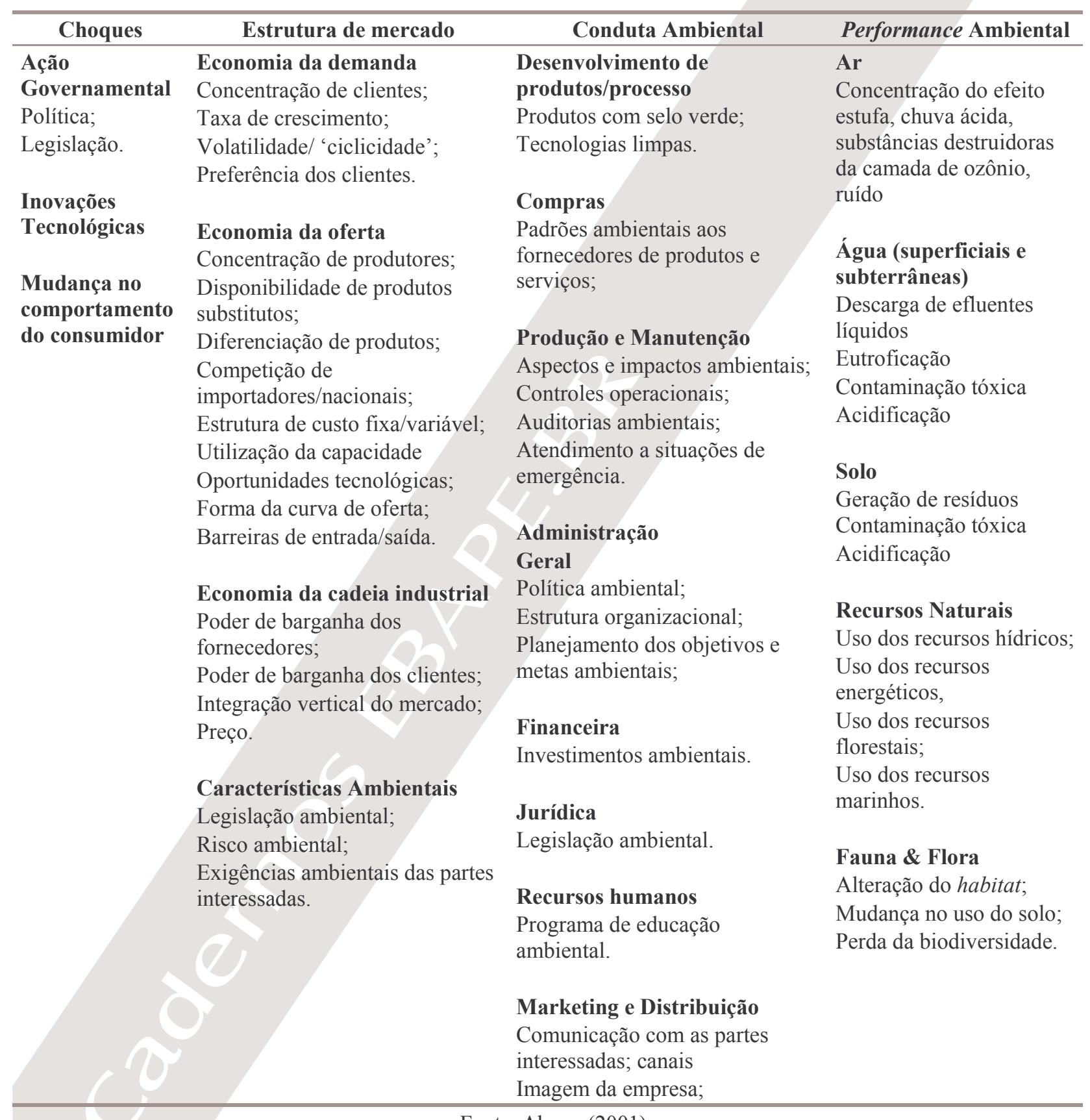

Fonte: Abreu, (2001). 
Os indicadores de estrutura de mercado do Modelo ECP-Ambiental abrangem, além dos fatores já abordados no paradigma SCP, as características sócio-ambientais compostas da: legislação e fiscalização ambiental; exigências das partes interessadas e os riscos ambientais decorrentes do processo produtivo. As pressões exercidas por essas características ambientais variam de acordo com a estrutura da indústria.

A regulamentação ambiental, segundo Porter (1999), atua criando pressões que motivam a inovação nas empresas, com a superação da inércia organizacional e na instigação do pensamento criativo. A regulamentação ambiental também cria a demanda pelo aprimoramento ambiental, até que as empresas e clientes sejam capazes de perceber e mensurar a ineficiência dos recursos como fonte de poluição. Porter (1999) assinala, contudo, que a regulamentação ambiental deve ser severa. A legislação branda, ao contrário, faz com que as empresas busquem soluções improvisadas ou secundárias. Assim, a regulamentação deve ser bastante rigorosa para promover uma efetiva inovação tecnológica.

Avaliando a atuação das partes interessadas, Maimon (1996) acrescenta que o consumidor tem ampliado a consciência ambiental, passando a uma preocupação com um consumo mais duradouro e contínuo, isto é, visando ao reaproveitamento maximizado de todos os recursos e componentes do sistema de produção e consumo.

Por fim, o risco ambiental é inerente ao processo produtivo e varia, principalmente, em função do volume de produção e das tecnologias adotadas. De acordo com o Manual de Impactos Ambientais (BNB, 1999), um dos aspectos de maior relevância na análise de um projeto de indústria têxtil é o elevado consumo de água, especialmente, nas etapas de acabamento, o que implica, conseqüentemente, a previsão de processos adequados de tratamentos de águas residuárias.

O conjunto de indicadores de conduta do modelo ECP-Ambiental foi desenvolvido, buscando refletir a qualidade da gestão ambiental na empresa ao longo de suas funções gerenciais, envolvendo: pesquisa e desenvolvimento de produtos e processos, compras, produção e manutenção, administração (geral, jurídico, financeiro e recursos humanos), marketing e distribuição. Para a construção dos indicadores de conduta ambiental, foram estudados os indicadores de resposta do modelo PSR (OECD, 1998), as variáveis utilizadas por Rodriguez e Ricart (1998) e a NBR ISO 14001 (1996), que estabelece as especificações e diretrizes para a implantação e uso do Sistema de Gestão Ambiental.

$\mathrm{Na}$ prática, exemplos de indicadores de conduta ambiental são: montante dos investimentos ambientais, números de multas e notificações, atividades de respostas às situações de emergência, número de auditorias conduzidas, alcance dos objetivos e metas ambientais, existência e compromissos assumidos na política ambiental, programas de educação ambiental implementados; exigências ambientais aos fornecedores e medidas de controle e monitoramento da poluição. Abreu et al (2002) demonstram que, dependendo do posicionamento frente aos indicadores de conduta, as organizações podem ser classificadas como empresas de conduta ambiental fraca, intermediária ou forte, conforme a matriz de características ambientais, apresentada no quadro 2 .

As empresas com uma conduta ambiental forte têm uma avaliação quantitativa da sua medida da performance ambiental. Entretanto, as empresas com uma conduta ambiental intermediária estão iniciando o processo de quantificação da performance ambiental. Por outro lado, as empresas com uma conduta ambiental fraca não praticam essas medições. 
Quadro 2. Matriz de características de Conduta Ambiental das Empresas

\begin{tabular}{|c|c|c|c|}
\hline \multirow[t]{2}{*}{ Funções Gerenciais } & \multicolumn{3}{|c|}{ Conduta ambiental } \\
\hline & Fraca & Intermediária & Forte \\
\hline Administração Geral & $\begin{array}{l}\text { - Não existe } \\
\text { gerência/departamento } \\
\text { ambiental na estrutura } \\
\text { organizacional } \\
\text { - nível gerencial é o mais } \\
\text { alto para o trato das } \\
\text { questões ambientais. } \\
\text { - Não assume } \\
\text { compromissos formais } \\
\text { em uma política } \\
\text { ambiental. } \\
\text { - A importância da questão } \\
\text { ambiental está limitada ao } \\
\text { atendimento dos } \\
\text { condicionantes da licença } \\
\text { de operação }\end{array}$ & $\begin{array}{l}\text { - Existe um responsável dentro } \\
\text { da estrutura organizacional. } \\
\text { - A diretoria é o nível mais alto } \\
\text { para o trato das questões } \\
\text { ambientais. } \\
\text { - Existem compromissos formais } \\
\text { estabelecidos na política } \\
\text { ambiental. } \\
\text { - A importância da questão não } \\
\text { está limitada ao atendimento à } \\
\text { legislação ambiental. } \\
\text { - Preocupadas com a imagem e } \\
\text { em alcançar novos mercados. }\end{array}$ & $\begin{array}{l}\text { - Existe uma } \\
\text { gerência/departamento de meio } \\
\text { ambiente na estrutura } \\
\text { organizacional. } \\
\text { - As questões ambientais são } \\
\text { tratadas em nível de presidência. } \\
\text { - Existem compromissos formais } \\
\text { em atender à legislação, } \\
\text { melhoria contínua dos processos } \\
\text { e prevenção da poluição. } \\
\text { - A importância da questão está } \\
\text { vinculada ao compromisso com } \\
\text { o desenvolvimento sustentável } \\
\text { - Preocupados com a imagem da } \\
\text { empresa }\end{array}$ \\
\hline Administração Jurídico & $\begin{array}{l}\text { - Não conhece a legislação } \\
\text { ambiental e não possui } \\
\text { instrumentos para } \\
\text { acompanhá-la. }\end{array}$ & $\begin{array}{l}\text { - Conhece parcialmente a } \\
\text { legislação ambiental. } \\
\text { - O acompanhamento do } \\
\text { atendimento à legislação é } \\
\text { realizado de forma não } \\
\text { sistematizada pelo responsável } \\
\text { pela área de meio ambiente. }\end{array}$ & $\begin{array}{l}\text { - Conhece integralmente a } \\
\text { legislação. } \\
\text { - Contrata consultoria externa para } \\
\text { a sua atualização. O } \\
\text { acompanhamento da legislação é } \\
\text { realizado pela gerência de meio } \\
\text { ambiente e o jurídico. }\end{array}$ \\
\hline $\begin{array}{l}\text { Administração } \\
\text { Financeiro }\end{array}$ & $\begin{array}{l}\text { - Os investimentos } \\
\text { ambientais representam } \\
\text { de } 0 \text { a } 1 \% \text { dos } \\
\text { investimentos totais. } \\
\text { - Definidos para atender à } \\
\text { legislação ambiental. } \\
\text { - Os ganhos financeiros } \\
\text { estão atrelados às vendas } \\
\text { de resíduos e subprodutos } \\
\text { sem alteração do processo } \\
\text { produtivo } \\
\text { - Não consegue } \\
\text { dimensionar esses } \\
\text { ganhos. }\end{array}$ & $\begin{array}{l}\text { - Os investimentos representam } \\
\text { entre } 1 \text { a } 2 \% \text { dos investimentos } \\
\text { totais. Definidos com base nos } \\
\text { projetos gerados internamente } \\
\text { de forma espontânea. } \\
\text { - Os ganhos financeiros estão } \\
\text { atrelados à redução do } \\
\text { desperdício, relacionada aos } \\
\text { insumos, água e energia } \\
\text { elétrica, e à comercialização } \\
\text { dos resíduos. }\end{array}$ & $\begin{array}{l}\text { - Os investimentos representam } \\
\text { mais de } 2 \% \text { dos investimentos } \\
\text { totais da empresa, definidos com } \\
\text { base nos objetivos e metas } \\
\text { ambientais. } \\
\text { - Os ganhos financeiros estão } \\
\text { atrelados à redução das perdas } \\
\text { de processo, } \\
\text { - Podem existir investimentos } \\
\text { ambientais sem retorno } \\
\text { financeiro. }\end{array}$ \\
\hline $\begin{array}{l}\text { Administração } \\
\text { Recursos Humanos }\end{array}$ & $\begin{array}{l}\text { - Não existe um programa } \\
\text { de educação ambiental. }\end{array}$ & $\begin{array}{l}\text { - Possui um programa de } \\
\text { educação ambiental voltado } \\
\text { para ações básicas, como a } \\
\text { coleta seletiva de lixo, e } \\
\text { desenvolvido informalmente } \\
\text { através de palestras. } \\
\text { - Freqüência anual. }\end{array}$ & $\begin{array}{l}\text { - Possui um programa de } \\
\text { educação ambiental voltado para } \\
\text { os funcionários e para a } \\
\text { comunidade. Diariamente são } \\
\text { realizados diálogos envolvendo } \\
\text { aspectos ambientais } \\
\text { - Realiza eventos anualmente, } \\
\text { como a semana de meio } \\
\text { ambiente e treinamento de } \\
\text { integração para os novos } \\
\text { funcionários. }\end{array}$ \\
\hline
\end{tabular}

Fonte: Abreu et al, (2002) 
Quadro 2. Matriz de características de Conduta Ambiental das Empresas (Continuação)

\begin{tabular}{|c|c|c|c|}
\hline \multirow[t]{2}{*}{ Funções Gerenciais } & \multicolumn{3}{|c|}{ Conduta ambiental } \\
\hline & Fraca & Intermediária & Forte \\
\hline $\begin{array}{l}\text { Desenvolvimento de } \\
\text { produtos \& processo }\end{array}$ & $\begin{array}{l}\text { - Não adota tecnologias } \\
\text { para minimizar o impacto } \\
\text { ambiental. }\end{array}$ & $\begin{array}{l}\text { - Investe na aquisição de } \\
\text { equipamentos com um menor } \\
\text { consumo de insumos. }\end{array}$ & $\begin{array}{l}\text { - Desenvolve tecnologias para } \\
\text { minimizar o impacto ambiental } \\
\text { de seus processos produtivos. } \\
\text { - Produtos certificados com o selo } \\
\text { verde }\end{array}$ \\
\hline $\begin{array}{l}\text { Produção e } \\
\text { Manutenção }\end{array}$ & $\begin{array}{l}\text { - Não possui um sistema de } \\
\text { gestão ambiental. } \\
\text { - Não avalia os impactos } \\
\text { ambientais de suas } \\
\text { atividades, produtos e } \\
\text { serviços. } \\
\text { - Não realiza auditorias } \\
\text { ambientais. } \\
\text { - Os controles operacionais } \\
\text { são atrelados aos insumos } \\
\text { da produção. } \\
\text { - Não adota uma } \\
\text { sistemática de melhoria } \\
\text { contínua para os } \\
\text { indicadores de } \\
\text { performance. }\end{array}$ & $\begin{array}{l}\text { - Está em processo de } \\
\text { implementação de um sistema } \\
\text { de gestão ambiental. } \\
\text { - Avalia os impactos ambientais } \\
\text { de suas atividades, produtos e } \\
\text { serviços. } \\
\text { - Processo imaturo de auditorias } \\
\text { ambientais. } \\
\text { - Controles operacionais } \\
\text { atrelados aos insumos de } \\
\text { processo e ao atendimento da } \\
\text { legislação ambiental. } \\
\text { - Os indicadores ambientais } \\
\text { foram estabelecidos através } \\
\text { dos padrões legais. } \\
\text { - Não existe uma sistemática de } \\
\text { melhoria contínua dos } \\
\text { indicadores de performance, } \\
\text { apenas conformidade legal. }\end{array}$ & $\begin{array}{l}\text { - Possui um sistema de gestão } \\
\text { ambiental certificado pela ISO } \\
14001 . \\
\text { - Faz o levantamento e avaliação } \\
\text { dos aspectos e impactos } \\
\text { ambientais de suas atividades, } \\
\text { produtos e serviços. } \\
\text { - Realiza auditorias ambientais } \\
\text { internas. } \\
\text { - Os indicadores ambientais foram } \\
\text { estabelecidos com base nos } \\
\text { padrões legais e em comparação } \\
\text { com outras unidades da empresa } \\
\text { ou histórico de desempenho. } \\
\text { - Adota uma sistemática de } \\
\text { melhoria contínua dos } \\
\text { indicadores ambientais. }\end{array}$ \\
\hline Marketing & $\begin{array}{l}\text { - Não possui uma } \\
\text { sistemática para tratar as } \\
\text { reclamações ambientais } \\
\text { das partes interessadas. } \\
\text { - Não produz relatórios } \\
\text { ambientais. } \\
\text { - Desconhece a } \\
\text { preocupação ambiental } \\
\text { por parte dos } \\
\text { concorrentes; } \\
\text { - Não identifica vantagens } \\
\text { competitivas com a } \\
\text { performance ambiental. }\end{array}$ & $\begin{array}{l}\text { - Utiliza a sistemática de } \\
\text { atendimento ao cliente para } \\
\text { tratamento das reclamações } \\
\text { das partes interessadas. } \\
\text { - Não produz relatórios } \\
\text { ambientais. } \\
\text { - Percebe a preocupação } \\
\text { ambiental de seus } \\
\text { concorrentes. } \\
\text { - Está começando a identificar } \\
\text { algumas vantagens } \\
\text { competitivas com a questão } \\
\text { ambiental. }\end{array}$ & $\begin{array}{l}\text { - Possui uma sistemática para } \\
\text { atendimento, acompanhamento e } \\
\text { registro das reclamações } \\
\text { ambientais das partes } \\
\text { interessadas. } \\
\text { - Disponibiliza relatórios } \\
\text { ambientais às partes } \\
\text { interessadas. Antecipa as } \\
\text { preocupações ambientais de seus } \\
\text { clientes. } \\
\text { - Alcança uma vantagem } \\
\text { competitiva através de uma } \\
\text { atuação ambientalmente } \\
\text { consciente e pró-ativa. }\end{array}$ \\
\hline Compras & $\begin{array}{l}\text { - Não adota padrões } \\
\text { ambientais aos } \\
\text { fornecedores de bens e } \\
\text { serviços. }\end{array}$ & $\begin{array}{l}\text { - Adota parcialmente padrões } \\
\text { ambientais aos seus } \\
\text { fornecedores de serviços. }\end{array}$ & $\begin{array}{l}\text { - Adota padrões ambientais para a } \\
\text { qualificação de todos os seus } \\
\text { fornecedores de bens e serviços }\end{array}$ \\
\hline Distribuição & $\begin{array}{l}\text { - Não identifica os riscos } \\
\text { ambientais na } \\
\text { distribuição de seus } \\
\text { produtos. }\end{array}$ & $\begin{array}{l}\text { - Identifica riscos de acidentes } \\
\text { na distribuição de seus } \\
\text { produtos } \\
\text { - Adota alguns procedimentos } \\
\text { de controle }\end{array}$ & $\begin{array}{l}\text { - Adota medidas rigorosas para } \\
\text { prevenção da poluição e de } \\
\text { acidentes }\end{array}$ \\
\hline
\end{tabular}

A performance ambiental considera os resultados mensuráveis da conduta ambiental. Segundo Murray et al (1996), os indicadores de performance ambiental são ditados por meio das preocupações sociais, das percepções públicas, dos desejos e necessidades das partes interessadas. 
Como ponto de partida para a identificação dos indicadores de performance ambiental foram analisados os indicadores de pressão e estado do modelo PSR (OECD, 1998) e os de carga/concentração de poluentes do modelo de performance ambiental e social (NORCIA, 1996). Norcia (1996) acrescenta ainda que as medidas diretas de performance ambiental são temas centrais na redução da poluição, na depleção da camada de ozônio e na biodiversidade. Os esforços devem ser voltados para a redução da carga de poluente ou concentração, ao decrescimento dos impactos ou na reabilitação do ecossistema.

O conjunto de indicadores de performance ambiental do modelo ECP-Ambiental considera, então, as preocupações definidas pelo modelo PSR (OECD, 1998), que atua nos compartimentos ar, água, solo, recursos naturais e, fauna e flora. A divisão em compartimento permite uma melhor compreensão dos indicadores de performance ambiental. Murray et al (1996) assinalam que, em virtude de o meio ambiente conter esses compartimentos e cada um deles ser largamente dependente do outro, em termos de medição e controle das descargas, são exigidos um número maior de indicadores ambientais para entender e descrever a performance ambiental. Também segundo Murray et al (1996), o uso de indicadores de performance ambiental é a melhor forma de medir e avaliar os avanços ambientais ao longo dos anos.

Porter (1999) argumenta que, além de reagir e influenciar a estrutura da indústria, as empresas devem escolher uma posição dentro dela. O posicionamento abrange a abordagem geral da firma para competir. Da mesma forma, usando o modelo ECP-Ambiental, as empresas podem definir qual o posicionamento estratégico, ambiental e obter êxito em relação aos seus competidores. A matriz de posicionamento estratégico, ambiental, apresentada na figura 2, demonstra a existência de seis tipos de posicionamentos estratégicos, os quais dependem da pressão a que está submetida a indústria e da resposta que dá, na forma de conduta ambiental da empresa, definida através da utilização da matriz de características ambientais apresentada no quadro 2 .

Figura 2. Matriz de Posicionamento Estratégico Ambiental.

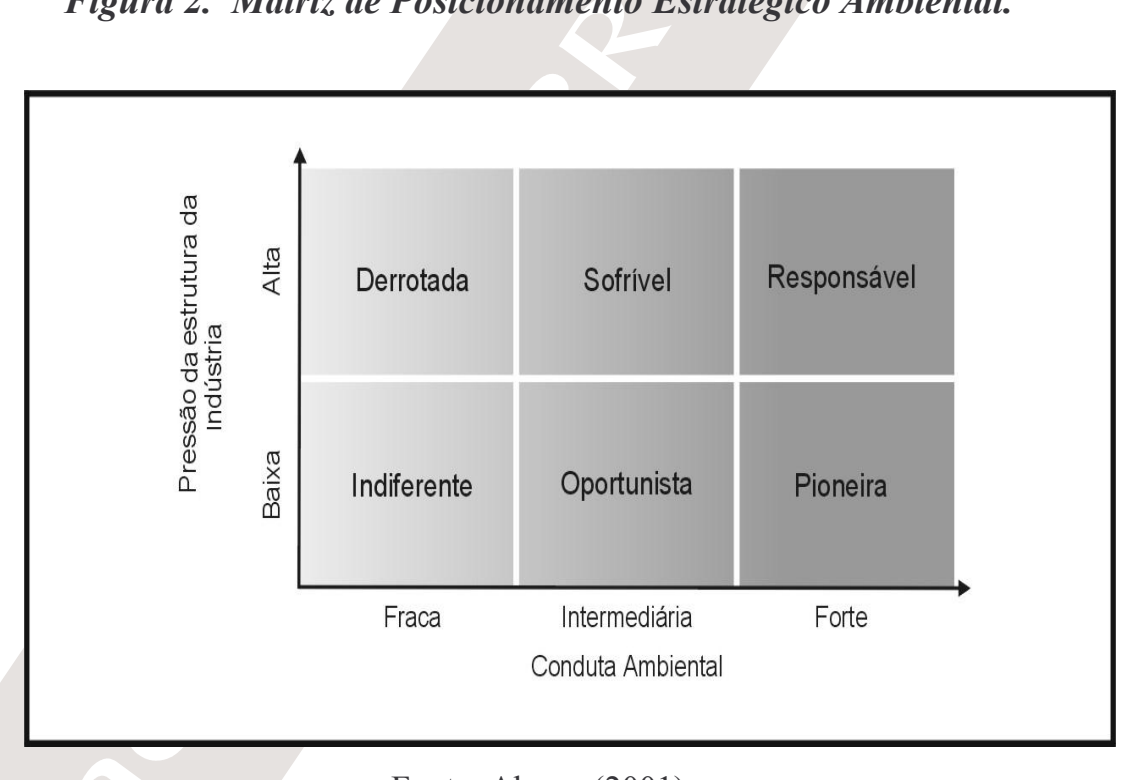

Fonte: Abreu, (2001)

A combinação das fontes individuais de pressão ambiental vai determinar se a pressão da estrutura da indústria é alta ou baixa. Abreu et al (2004) demonstram que a empresa sofre uma alta pressão da estrutura da indústria, quando o risco ambiental das atividades, produtos e serviços é alto, a regulamentação é rígida e a fiscalização atuante, e as exigências ambientais das partes interessadas são reais, demonstradas através de exigências legais ou contratuais. Por outro lado, a pressão da estrutura da indústria é considerada baixa, quando o risco ambiental é baixo, a regulamentação e a fiscalização são incipientes e as exigências das partes interessadas são apenas potenciais.

Delmas e Toffel (2004) propuseram um modelo que descreve como as partes interessadas externas, incluindo as agências de fiscalização ambiental, os clientes, os ativistas, a comunidade local e as associações industriais, 
impõem pressões às empresas. Os autores concluem que tanto as pressões institucionais como as características organizacionais das firmas influenciam a adoção de práticas (condutas) ambientais, e cada empresa reage de forma diversa, moderando esse efeito na estrutura da indústria.

A matriz [2]x[3] estabelece, portanto, "rótulos" que caracterizam o posicionamento estratégico das empresas, classificando-as como: derrotada, sofrível, responsável, indiferente, oportunista ou pioneira. Esses "rótulos" são adequados e suficientes para definir a estratégia ambiental adotada. A matriz de Posicionamento Estratégico Ambiental está estruturada nas seguintes hipóteses:

a) As variáveis - conduta ambiental e pressão da estrutura da indústria - estão relacionadas e são elementos do modelo ECP-Ambiental fundamentais para compreender como e por que as estratégias ambientais das empresas evoluem no tempo.

b) As ocorrências de choques implicam em mudanças de conduta ambiental das empresas, de acordo, com os ajustes nos posicionamentos estratégicos definidos no modelo ECP-Ambiental.

O estudo do funcionamento da matriz de posicionamento entre a conduta ambiental e a estrutura da indústria permite validar as hipóteses formuladas. Quando uma empresa que está sujeita a uma alta pressão da estrutura da indústria e adota uma conduta ambiental fraca, a avaliação da estratégia ambiental revela uma "empresa derrotada", com elevados riscos associados com a performance ambiental. Por outro lado, quando uma empresa está submetida a altas pressões da estrutura da indústria e atua com uma conduta ambiental, intermediária, é considerada uma "empresa sofrível" com relação à estratégia ambiental. As empresas, com uma conduta ambiental, forte, submetida a altas pressões da estrutura da sua indústria, atuam de acordo com a matriz, como uma "empresa responsável, buscando alcançar uma performance ambiental superior com vantagens competitivas.

O significado de "empresa indiferente" advém de uma empresa submetida a baixas pressões da estrutura da sua indústria e responde com uma conduta ambiental fraca, ou seja, a variável ambiental não influencia na definição da estratégia da empresa. Por outro lado, quando uma empresa está submetida a baixas pressões da estrutura da indústria e passa a adotar uma conduta intermediária, a empresa assume um posicionamento de forma "oportunista" em busca da vantagem competitiva, que as outras empresas concorrentes já alcançaram. O objetivo da empresa deve ser mover-se de "indiferente" para "oportunista". Firmas nesta categoria podem atuar tanto em mercados maduros, onde o potencial para crescimento é baixo, ou em mercados emergentes, onde o potencial não está completamente definido. No último caso, a base estratégica deve ser investir para crescimento. Nesse estágio é crucial adequar-se ou superar a concorrência.

Finalmente, as empresas que atuam sob uma baixa pressão serão consideradas "pioneiras" se adotarem uma conduta ambiental forte e, conseqüentemente, alcançarem uma vantagem competitiva frente aos seus concorrentes. Essas empresas agem de maneira pró-ativa e conseguem colher os frutos decorrentes da melhoria da imagem, de um maior controle do processo e da redução de custos inerentes à prevenção da poluição.

Porter (1999) ressalta que as primeiras empresas a agir transformam inovações em vantagens sustentáveis. A inovação em si pode ser copiada, mas as outras vantagens competitivas perduram ao longo do tempo. Firmas que operam em uma baixa pressão da estrutura da indústria e adotam uma conduta ambiental forte são normalmente líderes do mercado e inovadoras. A estratégia, nessa posição, deve ser focada na proteção da liderança e investir em tecnologias ambientais ou selos verdes.

\section{Metodologia}

$\mathrm{O}$ estudo desenvolvido classifica-se, quanto aos objetivos, como uma pesquisa descritiva e, com relação à abordagem do problema, como uma pesquisa de natureza 'quali-quantitativa'. Os elementos da pesquisa, necessários à aplicação do modelo ECP-Ambiental, envolveram o desenvolvimento de um instrumento de coleta de dados, a definição da amostra, o levantamento dos dados, com a condução de entrevistas diretas aos dirigentes das empresas selecionadas, e a análise e discussão dos resultados. 
$\mathrm{O}$ instrumento de coleta de dados foi estruturado em quatro partes: dados sobre a empresa, estrutura de mercado, conduta ambiental e performance ambiental. Em virtude de demandar informações de vários setores da empresa, a abordagem modular mostra-se necessária e, como vantagem, possibilita o preenchimento do instrumento de coleta de dados em etapas.

As informações, acerca da estrutura de mercado na qual a empresa está inserida, permitem entender os elementos que compõem a definição da sua estratégia competitiva. Essas informações envolvem a participação dos produtos no mercado e os seus principais clientes e fornecedores. Da mesma forma, procurou-se levantar informações relacionadas com os concorrentes significativos das empresas. As questões relacionadas com a conduta ambiental foram subdivididas entre os elementos que compõem as funções gerenciais, ou seja, administração geral, jurídico, financeiro e recursos humanos, pesquisa e desenvolvimento, compras, produção \& manutenção, marketing e distribuição. A pesquisa é concluída com levantamento das informações relacionadas com os indicadores de performance ambiental estabelecidos pela empresa, tomando como base as questões ambientais formuladas para cada um dos compartimentos classificados como: ar, água, solo, recursos naturais e fauna \& flora.

Inicialmente, foi feita uma pesquisa piloto no Ceará para identificar a aderência das respostas dos entrevistados aos indicadores propostos pelo modelo. Os dados foram, em seguida, levantados em oito empresas, sendo sete instaladas no estado do Ceará e uma empresa em Santa Catarina, de um total de dezenove empresas têxteis nesses estados. $\mathrm{O}$ acesso às empresa foi dificultado pelo baixo interesse despertado pela questão ambiental. A recusa das empresas às entrevistas envolvia a disponibilidade de tempo ou a autorização da matriz para prestar as informações. Usando o critério de similaridade tecnológica, a amostra contém empresas competidoras entre si, formando três grupos de análise: fiação ( 2 empresas), tecelagem plana (3 empresas) e malharia (3 empresas).

A quase totalidade das entrevistas desenvolveu-se no Ceará, em virtude do acesso às empresas. A empresa entrevistada em Santa Catarina é certificada pela ISO 14001, o que indica a adoção de um Sistema de Gestão Ambiental, sendo comparada com uma malharia no Ceará que se encontrava, no momento da pesquisa, em processo de implantação da ISO 14001.

O pólo têxtil, no Estado do Ceará, é caracterizado por empresas de fiação, tecelagem plana e malharia, de grande e médio porte, que utilizam o algodão como matéria-prima. A produção de fios, de tecidos planos e de malhas de algodão permite, então, que as empresas sejam comparadas entre si. Por outro lado, em Santa Catarina, estão instalados os grandes produtores nacionais de tecidos para cama, mesa e banho e, as malharias.

Nas empresas que implementaram, ou estão em processo de implantação de um Sistema de Gestão Ambiental, as entrevistas foram realizadas com os gerentes de meio ambiente. Entretanto, nas empresas que não possuem um sistema de gestão ambiental implantado, as entrevistas foram conduzidas com diretores industriais, gerentes de produção, engenheiros de processo ou gerentes de recursos humanos.

Após a coleta, os dados foram tabulados e analisados. Para os indicadores de estrutura de mercado, a pesquisa procurou identificar se as pressões da estrutura da indústria eram altas ou baixas. No caso da conduta ambiental foram identificados os comportamentos das empresas para cada função gerencial, visando a identificar se a conduta ambiental adotada pela empresa pesquisada era forte, intermediária ou fraca. Paralelamente, as informações sobre a conduta eram confirmadas com a identificação da performance ambiental. Esses resultados foram colocados na matriz de posicionamento estratégico, ambiental, permitindo a avaliação da estratégia ambiental no setor têxtil.

\section{Análise e Discussão dos Resultados \\ Pressões Ambientais da Estrutura de Mercado}

Analisando-se cada elemento do modelo ECP-Ambiental, observa-se que a estrutura é uma variável importante no ambiente competitivo, porque indica a capacidade que as empresas líderes têm de ordenar ou disciplinar o mercado. A indústria têxtil brasileira é caracterizada pela sua heterogeneidade no que se refere ao porte, à linha 
de produtos e ao estágio tecnológico e gerencial. Contudo, as empresas entrevistadas eram de grande e médio porte, modernas e competitivas.

A estrutura de mercado também é influenciada por características ambientais ditadas pela legislação ambiental, pelo risco ambiental e pelas exigências ambientais das partes interessadas, conforme apresentado na tabela 1. A análise do número de multas sofridas pelas empresas têxteis sinaliza a atuação dos órgãos de fiscalização ambiental nos estados em que a pesquisa foi realizada. A pesquisa revela que cinco empresas pesquisadas nunca foram multadas e apenas três foram notificadas.

Nesse sentido, os resultados obtidos, na pesquisa, indicam que a legislação ambiental constitui uma característica importante da estrutura da indústria, entretanto a atuação incipiente dos órgãos de fiscalização ambiental nos estados do Ceará e de Santa Catarina exerce uma baixa pressão na estrutura da indústria.

Durante a pesquisa, as empresas foram questionadas sobre os principais impactos ambientais decorrentes dos seus processos produtivos. As empresas têxteis admitem que o lançamento de efluente hídrico no corpo receptor e o consumo de energia elétrica são os principais impactos ambientais decorrentes da sua atividade produtiva. Cinco empresas têxteis estão preocupadas com o ruído emitido por suas instalações, em virtude das reclamações das comunidades vizinhas à unidade fabril e da possibilidade de físcalização pelo órgão governamental. Em menor escala, as empresas admitem o impacto da exaustão dos recursos naturais e da mudança climática. Somente uma empresa amplia suas preocupações para os resíduos perigosos gerados.

Tabela 1. Pressões Ambientais da Estrutura da Indústria

\begin{tabular}{|c|c|c|}
\hline Indicadores & Respostas & Número de Empresas no Setor Têxtil \\
\hline \multirow{3}{*}{$\begin{array}{l}\text { Número de Sanções } \\
\text { Administrativas Ambientais }\end{array}$} & Multas & - \\
\hline & Notificações & 3 \\
\hline & Nunca foi multado ou autuado & 5 \\
\hline \multirow[t]{10}{*}{ Impactos Ambientais } & Qualidade do efluente hídrico & 7 \\
\hline & Energia & 7 \\
\hline & Ruído & 5 \\
\hline & Exaustão dos recursos hídricos & 2 \\
\hline & Exaustão dos recursos naturais & 2 \\
\hline & Mudança climática & 2 \\
\hline & Geração de resíduos sólidos & 1 \\
\hline & Qualidade do ar & 1 \\
\hline & Destruição da camada de ozônio & 0 \\
\hline & 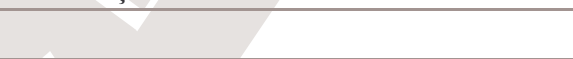 & \\
\hline \multirow{7}{*}{$\begin{array}{l}\text { Partes interessadas que } \\
\text { influenciam na estratégia } \\
\text { ambiental da empresa }\end{array}$} & Órgãos Governamentais de fiscalização & 7 \\
\hline & Clientes do mercado externo & 4 \\
\hline & Comunidade & 3 \\
\hline & Clientes do mercado interno & 3 \\
\hline & Agentes financiadores & 1 \\
\hline & Funcionários & 1 \\
\hline & Organizações Não-Governamentais & 1 \\
\hline \multirow{4}{*}{$\begin{array}{l}\text { Exigências ambientais dos } \\
\text { clientes }\end{array}$} & Selo verde & - \\
\hline & NBR ISO 14001 & - \\
\hline & Norma dos próprios clientes & 4 \\
\hline & Não têm exigências ambientais & 4 \\
\hline
\end{tabular}

Fonte: Abreu et al (2004) 
O Manual de Impactos Ambientais (BNB, 1999) admite que o setor têxtil pode desenvolver-se de maneira perfeitamente compatível com o meio ambiente, em todos os níveis de produção, considerando-se tanto as tecnologias de produção como as tecnologias de controle ambiental, disponíveis.

José (1996) argumenta que empresas, atuando em um setor com um alto risco ambiental, como a de produtos químicos, perigosos, devem dar um maior peso ao poder dos grupos de pressão, ao potencial para acidentes e aos registros ambientais, quando comparadas às firmas com baixo risco ambiental, como a indústria têxtil.

Os resultados da pesquisa demonstram que as empresas têxteis estão, principalmente, preocupadas com três impactos ambientais: efluentes líquidos, energia e ruído. Dessa forma, o impacto ambiental exerce uma baixa pressão ambiental sobre a estrutura da indústria têxtil.

Dentro da ótica das partes interessadas, os órgãos governamentais de fiscalização ambiental, prioritariamente, influenciam na estratégia ambiental das empresas. Observa-se, em seguida, que a comunidade e os clientes exercem influência na estratégia ambiental das empresas.

Metade das empresas têxteis pesquisadas tem clientes que possuem exigências ambientais, definidos por padrões próprios. Entretanto, essas exigências não foram expressas em termos de obrigações contratuais. Por outro lado, os clientes da outra metade de empresas entrevistadas não fazem exigências ambientais. Portanto, as exigências dos clientes são potenciais, e a pressão ambiental das partes interessadas é baixa.

Com base no exposto, conclui-se que as pressões ambientais exercem uma baixa pressão sobre a estrutura da indústria, não interferindo nas decisões estratégicas das empresas têxteis estudadas.

\section{A Conduta Ambiental}

Os resultados para a função gerencial, administração geral, apresentados na tabela 2, mostram que três empresas possuem uma política ambiental escrita e estão em processo de implementação, ou seja, de torná-la entendida por todos os funcionários. No entanto, o restante do universo pesquisado, representado por cinco empresas, não havia elaborado uma política ambiental. A importância das questões ambientais para metade das empresas têxteis entrevistadas está associada, principalmente, ao atendimento dos condicionantes estabelecidos na licença de operação. 
Tabela 2 Conduta ambiental para a função gerencial, administração geral

\begin{tabular}{lll}
\hline \multicolumn{1}{c}{ Indicadores } & \multicolumn{1}{c}{ Respostas } & Número de empresas do Setor Têxtil \\
\hline Política escrita & \multicolumn{1}{c}{ Sim } & 3 \\
\cline { 2 - 3 } & Não & 5 \\
\hline \multirow{2}{*}{$\begin{array}{l}\text { Importância das questões } \\
\text { ambientais }\end{array}$} & Atender a Licença de Operação & 4 \\
\cline { 2 - 3 } & Novos mercados & 3 \\
\cline { 2 - 3 } $\begin{array}{l}\text { Nível gerencial para o trato das } \\
\text { questões ambientais }\end{array}$ & Gedução do desperdício & 1 \\
\cline { 2 - 3 } & Direntes & 3 \\
\cline { 2 - 3 } $\begin{array}{l}\text { Meio ambiente na estrutura } \\
\text { organizacional }\end{array}$ & Presidência & 2 \\
\cline { 2 - 3 } & Qualidade e meio ambiente & 1 \\
\cline { 2 - 3 } & Manutenção e utilidades & 5 \\
\cline { 2 - 3 } & Atribuiçôes distribuídas entre as & \\
\hline
\end{tabular}

Fonte: Pesquisa realizada no setor têxtil em 2001

Entretanto, conforme observado, três empresas começaram a vislumbrar o alcance de mercados mais restritivos através de uma preocupação ambiental e para tanto, estão implementando sua política ambiental. Somente uma empresa entrevistada atrela o tratamento das questões ambientais à redução do desperdício. Na distribuição de freqüência observa-se que, em três das empresas pesquisadas, o nível gerencial é o responsável pelo trato das questões ambientais e, nas outras três empresas, a responsabilidade fica a cargo da diretoria. Em duas das empresas entrevistadas, no entanto, essa responsabilidade cabe à presidência.

Dentro da estrutura organizacional das empresas têxteis, observa-se que, em duas empresas, existe uma gerência/departamento que responde pela qualidade e meio ambiente. Por outro lado, em uma das empresas, essa responsabilidade está atribuída ao setor de manutenção e utilidades. Os resultados da pesquisa indicam, no entanto, que, em sua grande maioria, ou seja, em cinco empresas, as atribuições estão distribuídas entre os setores.

Analisando-se a função gerencial, compras, observa-se que sete das empresas pesquisadas não aplicam um padrão ambiental, mínimo para os seus parceiros de negócios. Apenas uma delas define padrões para os fornecedores de produtos e serviços. Esses resultados indicam, portanto, que os padrões ambientais não são considerados nos critérios de qualificação dos fornecedores das indústrias têxteis.

As empresas têxteis, em sua grande maioria, não conhecem a legislação aplicável aos seus aspectos ambientais, conforme apresentado na tabela 3. A distribuição de freqüência para a função gerencial, administração jurídica, mostra que cinco empresas não conhecem a legislação ambiental, aplicável aos aspectos ambientais de suas atividades, produtos ou serviços e, conseqüentemente, não acompanham a atualização dessa legislação. $\mathrm{O}$ conhecimento parcial da legislação acontece em duas empresas entrevistadas e apenas uma afirma conhecer toda a legislação ambiental, aplicável. 
Tabela 3. Conduta ambiental para a função gerencial, administração jurídico

\begin{tabular}{|c|c|c|}
\hline Indicadores & Respostas & Número de empresas do Setor Têxtil \\
\hline \multirow{3}{*}{$\begin{array}{l}\text { Conhecimento da legislação } \\
\text { ambiental aplicável }\end{array}$} & Não & 5 \\
\hline & Sim, parcialmente & 8 \\
\hline & Sim & 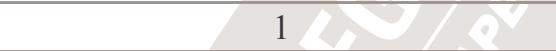 \\
\hline \multirow{3}{*}{$\begin{array}{l}\text { Acompanhamento da Legislação } \\
\text { Ambiental }\end{array}$} & Setor Jurídico & 8 \\
\hline & Consultoria externa & 2 \\
\hline & Não é acompanhado & 5 \\
\hline
\end{tabular}

Fonte: Pesquisa de campo realizada em 2001

Comparando-se esses resultados com aqueles obtidos pelo SENAI-CE (1997), para as empresas têxteis localizadas no Estado do Ceará, observa-se que esse percentual se mantém praticamente inalterado, ou seja, $60 \%$ das empresas entrevistadas naquele momento não conheciam a legislação ambiental. Quando o acompanhamento da legislação ambiental é analisado, observa-se que apenas uma das empresas executa esse serviço com seu próprio setor jurídico. Duas empresas contratam uma consultoria externa, em virtude da complexidade do trabalho e da carência de recursos internos. O restante das empresas pesquisadas, ou seja, cinco empresas, não possuem nenhum instrumento para acompanhar a atualização da legislação ambiental.

Em 1998, o BNDES, o SEBRAE e a CNI publicaram a pesquisa "Gestão Ambiental na Indústria Brasileira" com o objetivo de subsidiar os formuladores de políticas e as tomadas de decisão nos organismos públicos, com uma gama de informações sobre o tema. Essa pesquisa revelou que 53\% das empresas do setor têxtil realizavam investimentos ambientais entre 0 e $1 \%$ do total de investimentos no ano de 1997.

Comparando, agora, com a pesquisa de validação do modelo ECP-Ambiental nas empresas têxteis, observa-se uma redução nesse percentual. Os investimentos realizados em seis empresas estão restritos a $\mathrm{R} \$ 100$ mil anuais o que corresponde, no máximo, a $1 \%$ dos investimentos anuais realizados, conforme mostra a tabela 4 , para a função gerencial, administração financeira. O restante das empresas, ou seja, somente duas empresas realizam investimentos na ordem de 1 a $2 \%$ do volume total, e apenas uma empresa, na ordem de 2 a $5 \%$, o que significa, em ordem de grandeza, entre R $\$ 100$ mil a R $\$ 500$ mil.

$\mathrm{O}$ volume de investimentos em metade das empresas pesquisadas decorre de projetos gerados de forma espontânea dentro da empresa, buscando, principalmente, melhorias no processo produtivo. Em três das empresas são, entretanto, definidos objetivos e metas ambientais para aplicação dos investimentos. Por outro lado, o atendimento à legislação ambiental gera investimentos em apenas uma das empresas entrevistadas.

O retorno financeiro do investimento ambiental para metade das empresas entrevistadas está atrelado à redução do desperdício de água, de energia elétrica, de insumos do processo e de recursos naturais, principalmente, o algodão. Em virtude do processo de beneficiamento gerar uma grande quantidade de resíduos, a sua venda constitui uma fonte de renda em três empresas, através de programas de coleta seletiva. Em uma única empresa entrevistada, os ganhos financeiros com a questão ambiental não são identificados. 
Tabela 4. Conduta ambiental para a função gerencial, administração financeira

\begin{tabular}{lll}
\hline \multicolumn{1}{c}{ Indicadores } & \multicolumn{1}{c}{ Respostas } & Número de empresas do Setor Têxtil \\
\hline Montante investido & $0-\mathrm{R} \$ 100 \mathrm{mil}$ & 6 \\
\cline { 2 - 3 } & $\mathrm{R} \$ 100 \mathrm{mil}-\mathrm{R} \$ 500 \mathrm{mil}$ & 2 \\
\hline Percentual investido & 0 a $1 \%$ & 5 \\
\cline { 2 - 3 } & 1 a $\%$ & 2 \\
\cline { 2 - 3 } $\begin{array}{l}\text { Definição do volume de } \\
\text { investimento }\end{array}$ & Projetos espontâneos & 1 \\
\cline { 2 - 3 } & Objetivos e metas ambientais & 4 \\
\cline { 2 - 3 } $\begin{array}{l}\text { Retorno financeiro do } \\
\text { investimento ambiental }\end{array}$ & Atendimento à Legislação Ambiental & 3 \\
& Redução do desperdício (água, energia, & 4 \\
\cline { 2 - 3 } & recursos naturais) & 3 \\
\cline { 2 - 3 } & Venda de resíduos & 1 \\
\hline
\end{tabular}

Fonte: Pesquisa de campo realizada em 2001

A tabela 5 apresenta a função gerencial, produção e manutenção, mostrando a importância da variável ambiental dentro do processo produtivo da empresa. No setor têxtil foi entrevistada uma empresa certificada pela ISO 14001 e outras duas, que estavam em processo de certificação pela mesma norma. Por outro lado, no restante do universo de amostragem, três delas tinham planos de implantar o SGA em longo prazo; e, em outras duas empresas, o compromisso com a implantação do sistema de gestão ambiental não fazia parte do planejamento.

Como conseqüência da implantação do sistema de gestão ambiental certificável pela ISO 14001, as três empresas realizam uma avaliação continuada dos aspectos e impactos ambientais e passam por auditorias ambientais internas e externas. Quando o controle operacional dos aspectos ambientais, em uma indústria têxtil, é estudado, observa-se que todas as empresas definiram controles para a água, como conseqüência da escassez e do elevado consumo nos processos de tingimento e de acabamento. A energia elétrica é outro insumo fundamental na fiação e tecelagem, levando ao estabelecimento de controles operacionais em sete empresas, que buscam a redução do seu consumo. Além da água e da energia elétrica, o ruído é uma outra preocupação para cinco empresas, em virtude de terem sofrido alguma reclamação da comunidade vizinha ou de estarem sujeitos, os seus funcionários, a problemas de perda auditiva.

Os efluentes líquidos causam um elevado impacto ambiental em qualquer processo têxtil, entretanto foi verificado que apenas metade das empresas entrevistadas percebe a necessidade de estabelecer controles operacionais para adequar seus efluentes líquidos aos padrões estabelecidos pela legislação. $\mathrm{O}$ mesmo comportamento foi observado para os resíduos sólidos, onde metade das empresas possui controles operacionais específicos. Os energéticos, que englobam vapor, ar comprimido, óleo combustível e gás natural, são controlados em apenas duas das empresas entrevistadas. 
Tabela 5. Conduta ambiental para a função gerencial produção e manutenção

\begin{tabular}{|c|c|c|}
\hline Indicadores & Respostas & Número de empresas do Setor Têxtil \\
\hline \multirow{4}{*}{$\begin{array}{l}\text { Implantação de um } \\
\text { Sistema de Gestão } \\
\text { Ambiental }\end{array}$} & Certificado pela ISO 14001 & 1 \\
\hline & Em processo de certificação pela ISSO 14001 & 2 \\
\hline & Está nos planos da empresa & $3 / 27$ \\
\hline & Não está nos planos da empresa & 2 \\
\hline \multirow[t]{2}{*}{$\begin{array}{l}\text { Avaliação dos } \\
\text { impactos ambientais }\end{array}$} & $\begin{array}{l}\text { Continuamente, através do levantamento dos } \\
\text { aspectos e impactos ambientais significativos }\end{array}$ & 3 \\
\hline & Não faz avaliação dos impactos ambientais & 5 \\
\hline \multirow{2}{*}{$\begin{array}{l}\text { Freqüência de } \\
\text { auditorias } \\
\text { ambientais }\end{array}$} & Semestral & 3 \\
\hline & Não fez auditoria ambiental & 5 \\
\hline \multirow{7}{*}{$\begin{array}{l}\text { Controles } \\
\text { operacionais }\end{array}$} & Conservação da Água & 8 \\
\hline & Conservação de Energia elétrica & 7 \\
\hline & Controle do Ruído & 5 \\
\hline & Tratamento dos Efluentes líquidos & 4 \\
\hline & Coleta Seletiva & 4 \\
\hline & $\begin{array}{l}\text { Monitoramento das Emissões atmosféricas das } \\
\text { fontes fixas }\end{array}$ & 3 \\
\hline & $\begin{array}{l}\text { Conservação de Energéticos (vapor, ar } \\
\text { comprimido, óleo combustível, gás natural) }\end{array}$ & 2 \\
\hline
\end{tabular}

Fonte: Pesquisa de campo realizada em 2001

A pesquisa do SENAI-CE (1997) revelou que as empresas têxteis, naquele momento, estavam preocupadas em estabelecer controles operacionais, prioritariamente, para o ruído, a água de processo e os resíduos sólidos. No cenário nacional, através da pesquisa do BNDES, SEBRAE e CNI (1998), as empresas estavam preocupadas em controlar prioritariamente os efluentes líquidos, os resíduos sólidos e o ruído. Comparando-se esses resultados, observa-se que a questão da água de processo e o ruído são preocupações inerentes ao processo têxtil. Entretanto, considerando-se o cenário de crise de energia elétrica, que atua como um choque, esse insumo passa a ser controlado através das políticas de governo que obrigam a redução do consumo.

Os resultados obtidos para a função gerencial, administração de recursos humanos, apresentados na tabela 6 , indicam que metade das empresas entrevistadas não desenvolve nenhum programa de educação ambiental com os funcionários. O restante da amostra apresenta algum tipo de programas de educação ambiental.

Tabela 6. Conduta ambiental para a função gerencial, administração de recursos humanos

\begin{tabular}{|c|c|c|}
\hline Indicadores & Respostas & Número de empresas do Setor Têxtil \\
\hline \multirow{5}{*}{$\begin{array}{l}\text { Existência de um } \\
\text { Programa de Educação }\end{array}$} & Não existe um Programa de Educação & 4 \\
\hline & Ambiental & \\
\hline & Programa 3R & 2 \\
\hline & $\begin{array}{l}\text { Programas de Conservação de Água, Energia, } \\
\text { Produtos Químicos }\end{array}$ & 1 \\
\hline & Informalmente, através de palestras & 1 \\
\hline \multirow{4}{*}{$\begin{array}{l}\text { Freqüência de } \\
\text { treinamento no Programa } \\
\text { de Educação Ambiental }\end{array}$} & Mensal & 1 \\
\hline & Anual & 2 \\
\hline & Não possui uma freqüência definida & 1 \\
\hline & Não são treinados & 4 \\
\hline
\end{tabular}

Fonte: Pesquisa de campo realizada em 2001 
Em uma das empresas entrevistadas, o programa tem sido desenvolvido, com uma freqüência mensal, visando à conservação de água, de energia e de produtos químicos. Um outro programa de redução-reciclagemreutilização, designado de $3 R$, é desenvolvido com freqüência anual em duas das empresas. Informalmente, através de palestras são tratadas as questões ambientais em uma das empresas pesquisadas, com uma freqüência não definida.

Os produtos têxteis de uma das empresas entrevistadas são certificados pelo selo alemão Ôkotex, atribuído pelo Hohensteiner Textilinstitut, entidade oficial envolvida com a pesquisa e a análise ambiental, relacionada à indústria têxtil, conforme apresentada na tabela 7, para a função gerencial, pesquisa e desenvolvimento, envolvendo produtos com selos verdes. Uma das empresas entrevistadas tem planos para certificação de seus produtos com o Ôkotex, entretanto a obtenção do selo não está sendo planejada para as outras seis empresas entrevistadas.

Tabela 7. Conduta ambiental para a função gerencial, pesquisa e desenvolvimento

\begin{tabular}{|c|c|c|}
\hline Indicadores & Respostas & Número de empresas do Setor Têxtil \\
\hline \multirow{3}{*}{$\begin{array}{l}\text { Selo verde para os produtos } \\
\text { fabricados }\end{array}$} & Produto certificado & 1 \\
\hline & Está nos planos da empresa & 1 \\
\hline & Não está nos planos da empresa & 6 \\
\hline \multirow{3}{*}{$\begin{array}{l}\text { Adoção de tecnologias para } \\
\text { minimizar os impactos ambientais }\end{array}$} & Tecnologias limpas & 1 \\
\hline & $\begin{array}{l}\text { Aquisição de equipamentos com } \\
\text { um menor consumo de insumos }\end{array}$ & 5 \\
\hline & $\begin{array}{l}\text { Não adota tecnologias para } \\
\text { minimizar o impacto ambiental }\end{array}$ & 2 \\
\hline
\end{tabular}

Fonte: Pesquisa de campo realizada em 2001

Verificando-se a adoção de tecnologias para minimizar o impacto ambiental, observa-se que apenas uma empresa adota tecnologias limpas, enquanto cinco procuram adequar seu parque industrial com equipamentos modernos que operam com um baixo consumo de matéria-prima, água e energia elétrica. O restante, ou seja, duas empresas, não adota tecnologias para minimizar o impacto ambiental.

A denúncia da vizinhança foi apontada como uma das principais origens das punições ambientais na pesquisa do BNDES, SEBRAE e CNI (1998). Para a função gerencial marketing, os resultados na tabela 8 mostram que as reclamações ou sugestões das partes interessadas são tratadas de forma variável e não são registradas em cinco das empresas entrevistadas.

\section{Tabela 8. Conduta ambiental para a função gerencial, marketing}

\begin{tabular}{llc}
\hline \multicolumn{1}{c}{ Indicadores } & \multicolumn{1}{c}{ Respostas } & Número de empresas do Setor Têxtil \\
\hline Tratamento das reclamações ou & $\begin{array}{l}\text { Procedimento e canais de } \\
\text { sugestões das partes interessadas }\end{array}$ & 1 \\
\cline { 2 - 3 } & $\begin{array}{l}\text { comunicação estruturados } \\
\text { reclamações governamentais }\end{array}$ & 2 \\
\cline { 2 - 3 } & $\begin{array}{l}\text { Variável em função da } \\
\text { reclamação, mas não registra as } \\
\text { reclamações. }\end{array}$ & 5 \\
\hline Relatório ambiental & $\begin{array}{l}\text { Não } \\
\text { Freqüência do relatório ambiental }\end{array}$ & $\begin{array}{l}\text { Não produz relatórios de } \\
\text { performance ambiental }\end{array}$ \\
\hline
\end{tabular}

Fonte: Pesquisa de campo realizada em 2001

Outras duas empresas encaminham ao setor jurídico as reclamações dos órgãos governamentais e apenas uma empresa possui procedimentos e canais de comunicação, estruturados para atender as reclamações das partes 
interessadas. Um elemento importante de divulgação da conduta e da performance ambiental das empresas consiste no relatório ambiental. Contudo, nenhuma das empresas entrevistadas produz esse tipo de relatório.

A última função gerencial, estudada, envolve a distribuição dos produtos; cinco empresas entrevistadas não identificam risco ambiental na distribuição de seus produtos. O restante, ou seja, três empresas, identifica o risco e adota medidas preventivas e corretivas, principalmente, em função do alto valor agregado do produto.

Tomando, como base, a matriz de características de condutas ambientais (quadro 2), observa-se que existe uma uniformidade de respostas para as condutas forte, intermediária e fraca. A pesquisa revela que apenas uma empresa entrevistada assume os indicadores mais restritivos de conduta ambiental, definidos como uma conduta ambiental, forte. Por outro lado, duas empresas ficam em uma situação intermediária, assumindo uma conduta ambiental intermediária, e a grande maioria, ou seja, cinco empresas entrevistadas adotam os indicadores mais brandos de conduta ambiental, definidos como uma conduta ambiental fraca.

\section{A Performance Ambiental}

A pesquisa revelou que as empresas têxteis, entrevistadas, estabeleceram indicadores de performance ambiental através dos padrões legais, em duas das empresas, e outras duas, através da comparação com outras unidades da empresa. O restante das empresas, o que representa metade das entrevistadas, não possui indicadores de performance ambiental, conforme mostra a tabela 9 .

O acompanhamento mensal dos indicadores ambientais ocorre em uma única empresa entrevistada, e existe um grupo de trabalho multidisciplinar composto de representantes dos setores envolvidos, avaliados periodicamente pela alta administração da empresa. Esse grupo tem a responsabilidade de definir um plano de trabalho, contemplando ações de redução do consumo de matéria-prima e de insumos de processo. Outras duas empresas adotam a sistemática de acompanhamento dos objetivos e metas ambientais. Entretanto, o restante do universo pesquisado, que corresponde a cinco empresas, não adota nenhuma sistemática de melhoria contínua dos indicadores de performance ambiental. As justificativas ficaram restritas à falta de importância desses indicadores, ou nunca houve exigências do órgão ambiental quanto à definição de indicadores.

Ao longo da pesquisa, pretendia-se obter dados quantitativos sobre a performance ambiental, de modo que fosse permitido comparar as empresas concorrentes. Contudo, as empresas têxteis não disponibilizaram esses dados, ou, em sua grande maioria, as empresas não realizavam essas medidas de performance ambiental.

A ausência de estatísticas sobre a emissão de poluentes também foi confirmada por Rodriguez e Ricart (1998). Em virtude da falta de dados quantitativos, os pesquisadores optaram por realizar uma avaliação qualitativa da gestão ambiental das empresas espanholas. Segundo os autores, quando as empresas espanholas medem a sua performance ambiental utilizam diferentes indicadores, relacionados aos aspectos técnicos de sua própria gestão ambiental, como o consumo de água e energia ou a percentagem de resíduos.

\section{Tabela 9. Distribuição de freqüências para a definição de indicadores de performance ambiental}

\begin{tabular}{|c|c|c|}
\hline Indicadores & Respostas & Número de empresas do Setor Têxtil \\
\hline \multirow{3}{*}{$\begin{array}{l}\text { Definição de indicadores de } \\
\text { performance ambiental }\end{array}$} & Através dos padrões legais & 2 \\
\hline & $\begin{array}{l}\text { Comparação com outras unidades fabris } \\
\text { da empresa }\end{array}$ & 2 \\
\hline & $\begin{array}{l}\text { Não possui indicadores de performance } \\
\text { ambiental }\end{array}$ & 4 \\
\hline \multirow[t]{3}{*}{$\begin{array}{l}\text { Adoção de uma sistemática } \\
\text { de melhoria dos indicadores } \\
\text { ambientais }\end{array}$} & $\begin{array}{l}\text { Acompanhamento mensal dos indicadores } \\
\text { ambientais e definição de um plano de } \\
\text { ação preventiva e/ou corretiva }\end{array}$ & 1 \\
\hline & $\begin{array}{l}\text { Acompanhamento dos objetivos e metas } \\
\text { ambientais }\end{array}$ & 2 \\
\hline & $\begin{array}{l}\text { Não adota uma sistemática de melhoria } \\
\text { dos indicadores ambientais }\end{array}$ & 5 \\
\hline
\end{tabular}




\begin{tabular}{lll}
\hline Não estabelecimento dos & Não vê importância & 4 \\
\cline { 2 - 2 } $\begin{array}{l}\text { indicadores de performance } \\
\text { ambiental }\end{array}$ & Não foi exigido dos órgãos de fiscalização & 1 \\
\hline
\end{tabular}

Fonte: Pesquisa de campo realizada em 2001

Tomando, como base, a análise qualitativa do desempenho realizada por Rodriguez e Ricart (1998), a tabela 10 apresenta a distribuição de freqüência dos indicadores de performance ambiental. Os resultados ultrapassam $100 \%$ porque as empresas podem assinalar mais de uma opção. Na descrição da pesquisa optou-se, portanto, por percentuais para permitir uma visão de todo o universo amostrado.

Tabela 10. Distribuição de freqüências dos indicadores de performance ambiental do setor têxtil.

\begin{tabular}{|c|c|c|c|c|}
\hline \multirow[t]{2}{*}{ Compartimento Ambiental } & \multirow[t]{2}{*}{ Monitoramento } & & \multicolumn{2}{|c|}{ Setor Têxtil } \\
\hline & & & $\mathrm{N}$ & $(\%)$ \\
\hline \multirow{15}{*}{$\begin{array}{l}\text { Água (superficial e } \\
\text { subterrânea) }\end{array}$} & Vazão de efluente & $\mathrm{m}^{3} / \mathrm{ano}$ & 6 & 75,0 \\
\hline & $\mathrm{PH}$ & & 2 & 25,0 \\
\hline & Temperatura & ${ }^{\circ} \mathrm{C}$ & 2 & 25,0 \\
\hline & Sólidos suspensos totais & $\mathrm{mg} / \mathrm{L}$ & 1 & 12,5 \\
\hline & Demanda bioquímica de oxigênio & $\mathrm{mg} / \mathrm{L}$ & 2 & 25,0 \\
\hline & Remoção de DBO & $\%$ & 1 & 12,5 \\
\hline & Demanda química de oxigênio & $\mathrm{mg} / \mathrm{L}$ & 1 & 12,5 \\
\hline & Remoção de DQO & $\%$ & 1 & 12,5 \\
\hline & Cádmio & $\mathrm{mg} / \mathrm{L}$ & 1 & 12,5 \\
\hline & Mercúrio & $\mathrm{mg} / \mathrm{L}$ & 1 & 12,5 \\
\hline & Níquel & $\mathrm{mg} / \mathrm{L}$ & 1 & 12,5 \\
\hline & Chumbo & $\mathrm{mg} / \mathrm{L}$ & 1 & 12,5 \\
\hline & Remoção de cor & $\%$ & 1 & 12,5 \\
\hline & Cor do efluente & & 1 & 12,5 \\
\hline & Lodo da ETE/DBO removida & $\%$ & 1 & 12,5 \\
\hline $\mathrm{Ar}$ & $\mathrm{CO}_{2}$ & ton/ano & 3 & 37,5 \\
\hline \multirow[t]{4}{*}{ Solo } & Resíduos - Classe I & ton/ano & 1 & 12,5 \\
\hline & Resíduos sólidos reciclados & ton/ano & 3 & 37,5 \\
\hline & Resíduo seco para aterro & ton/ano & 1 & 12,5 \\
\hline & Lodo da ETE/ ton de malha beneficiada & $\%$ & 1 & 12,5 \\
\hline \multirow[t]{3}{*}{ Recursos Naturais } & Água & $\mathrm{m}^{3} /$ ano & 3 & 37,5 \\
\hline & Energia elétrica & $\mathrm{KW} / \mathrm{h}$ & 7 & 100 \\
\hline & Líquidos combustíveis & ton/ano & 1 & 12,5 \\
\hline
\end{tabular}

Fonte: Pesquisa de campo realizada em 2001

As empresas têxteis entrevistadas medem, em $75 \%$ dos casos, a vazão dos efluentes hídricos e em $25 \%$ realizam medições de temperatura, de pH e de Demanda Bioquímica de Oxigênio (DBO), todos por exigência do órgão de fiscalização. Em 12,5\% das empresas entrevistadas são medidos, também, os sólidos suspensos, totais, a demanda química de oxigênio (DQO), o percentual de remoção de DBO, e alguns metais pesados como: cádmio, mercúrio, níquel e chumbo. Considerando-se a forte presença de cor no efluente hídrico, em $12,5 \%$ das empresas entrevistadas são analisadas a cor e sua remoção. O outro indicador de performance da estação de tratamento de efluentes (ETE) consiste no percentual de lodo da ETE por DBO removida.

Para o compartimento ar, 37,5\% das empresas entrevistadas medem a emissão de gás carbônico, o restante não realiza nenhuma das medidas associadas a esse compartimento. Para o compartimento solo, em 37,5\% das 
empresas é medida a quantidade de resíduos sólidos recicláveis e, em 12,5\% das empresas, a quantidade de resíduos classe I, de resíduo seco para aterro e o percentual de lodo da ETE por ton de malha beneficiada, o que mostra o uso da produção como 'normalizador' do indicador.

Com relação aos recursos naturais são monitoradas: a energia elétrica, consumida em $100 \%$ das empresas pesquisadas, a vazão de água, consumida em $37,5 \%$ e, em $12,5 \%$, a quantidade de líquidos combustíveis, consumidos. Finalmente, analisando-se o comportamento do compartimento fauna e flora e considerando-se a localização das empresas em distritos industriais, não existe nenhuma preocupação associada. Os resultados obtidos, na pesquisa para validação do modelo ECP-Ambiental, comprovam a necessidade de estabelecer indicadores de performance ambiental que permitam a comparação das empresas e a definição das condutas ambientais que efetivamente conduzam à sustentabilidade.

\section{O Posicionamento Estratégico, Ambiental, da Indústria Têxtil}

As companhias geralmente iniciam seu processo de resposta às pressões "verdes," modificando suas condutas na base do "somente o necessário". Esse é o mais reativo padrão de mudanças, movido por pressões regulatórias ou de mercado. Na fase de adaptação e antecipação os valores ambientais estão ligados aos valores corporativos. Nessa fase ocorre o questionamento de antigos paradigmas. Na fase seguinte, de inovação, as companhias passam a reexaminar e reavaliar, seriamente, seus objetivos ambientais e alcançar um estágio onde esses objetivos estão institucionalizados em todas as partes da companhia (POST ; ALTMAN, 1994).

A pesquisa revela que as empresas têxteis estão submetidas a uma baixa pressão da estrutura da indústria, caracterizada por um baixo risco ambiental, uma regulamentação e fiscalização incipientes e, também, às partes interessadas, que apresentam apenas demandas potenciais. A pesquisa demonstra que as empresas têxteis apresentam condutas ambientais distintas. Tomando-se os resultados das condutas ambientais adotadas e a baixa pressão ambiental da estrutura da indústria têxtil, foi definido o posicionamento estratégico ambiental das empresas pesquisadas.

O posicionamento estratégico, ambiental, é realizado com base na matriz, apresentada na figura 2 , utilizada para melhorar a formulação e a implementação das estratégias dentro das firmas. Uma vez que a posição relativa de diferentes firmas é determinada, fica mais fácil, para o gestor, elaborar planos para alcançar a competitividade.

De acordo com a matriz de posicionamento estratégico, ambiental, cinco empresas pesquisadas adotam um posicionamento indiferente, ou seja, adotam uma conduta fraca sob baixas pressões ambientais. A pesquisa revela que essas empresas não distinguem nenhuma vantagem competitiva e, também, não percebem a preocupação ambiental de seus concorrentes. Por outro lado, duas empresas adotam uma conduta ambiental intermediária e estão sujeitas a baixas pressões, assumindo, então um posicionamento de forma oportunista em busca da vantagem competitiva, que as outras empresas concorrentes já alcançaram.

Finalmente, apenas uma empresa adota uma conduta ambiental forte e atua sob uma baixa pressão, sendo considerada pioneira. As empresas pioneiras percebem, desde cedo, as vantagens competitivas e agem agressivamente, para explorá-las. Adotando um posicionamento pró-ativo, essa empresa pioneira tem conseguido vantagens competitivas através da melhoria da imagem, que passou a ser vista pela comunidade (escolas, universidades e empresas vizinhas), colaboradores, fornecedores, clientes e órgão governamentais como uma empresa comprometida com a preservação ambiental. Essa postura resultou em uma maior confiança por parte da comunidade e dos órgãos ambientais; com a participação consultiva da empresa em fóruns ambientais, a redução do risco de multas e processos por não conformidades legais relativa a crimes ambientais.

Outra vantagem competitiva está associada à redução do custo pela redução de consumos e dos desperdícios em decorrência da otimização de processos. Cabe destacar, principalmente, a possibilidade de competir em 
mercados ambientalmente exigentes e a melhoria do nível de conscientização dos colaboradores, quando a empresa decide atuar em ambiente voltado para a melhoria contínua.

\section{Considerações finais}

Tomando como ponto de partida o paradigma SCP, o artigo apresentou o Modelo de Avaliação da Estratégia Tripla (ECP-Triplo) e, de forma detalhada, sua dimensão ambiental (ECP-Ambiental), como uma proposta metodológica que responde à necessidade de readequação do "tripé da sustentabilidade empresarial", pensando não apenas na variável econômica, como influenciadora na competitividade, mas também, nas dimensões ambiental e social.

O desenvolvimento do modelo ECP-Ambiental exige a compreensão da estrutura da indústria, o estabelecimento dos indicadores de conduta ambiental, por elemento de suas funções gerenciais; além da seleção dos indicadores de performance ambiental que permitem a comparação e a classificação de empresas e setores industriais e que são resultados de condutas ambientais específicas. A pesquisa no setor têxtil indica que a legislação ambiental, o risco ambiental e as exigências ambientais das partes interessadas atuam como uma baixa pressão ambiental da estrutura da indústria.

A localização da firma, na matriz de posicionamento estratégico, ambiental, baseia-se na avaliação dos indicadores de conduta ambiental e das características ambientais da estrutura da indústria. Com relação à conduta ambiental, apenas uma empresa respondeu aos indicadores mais restritivos do modelo ECP-Ambiental, caracterizando-a como uma empresa de conduta ambiental forte. Cinco empresas adotam os indicadores mais brandos, que as identificam como empresas com conduta ambiental, fraca, e duas empresas adotam uma conduta ambiental, intermediária. Por outro lado, esses resultados da conduta ambiental foram comprovados durante a análise da performance ambiental das empresas têxteis.

De acordo com a matriz, a posição "pioneira" é a mais vantajosa estrategicamente e demonstra um comprometimento das empresas em direção a sustentabilidade. Duas empresas estão posicionadas na célula "oportunistas"; essas empresas devem identificar suas vulnerabilidades e investir em melhorias tecnológicas e processos de gestão ambiental. O restante das empresas posicionou-se na célula "indiferente". A posição ambiental é, no entanto, dinâmica, e choques podem fazer com que a pressão aumente de baixa para alta. Os acidentes ambientais, por exemplo, podem modificar as preocupações das partes interessadas, e a posição estratégica, mudar de "indiferente" para "derrotada".

A duração e o padrão do movimento, ao longo da matriz, dependem da tendência dos padrões de regulação, das estratégias dos competidores, das potencialidades do mercado, da disponibilidade tecnológica e da viabilidade financeira. Os movimentos, ao longo da matriz, podem, também, ser limitados por fatores que estão fora de controle dos gestores, limitando as escolhas estratégicas que podem ser feitas. Por exemplo, a movimentação vertical pode ser limitada por fatores da estrutura de mercado, como o tamanho e a taxa de crescimento anual do mercado e as barreiras de entrada e saída. Paralelamente, as políticas governamentais e as demandas das partes interessadas estão fora do controle de uma firma individual. Por outro lado, no movimento horizontal da conduta ambiental, a empresa pode manipular fatores, tais como: a conscientização e a motivação ambiental, a alocação de recursos, o uso eficiente de energia e dos insumos, os padrões de segurança operacional e os níveis de emissões.

O uso do modelo ECP-Ambiental contribui, portanto, para que as empresas avaliem, de forma simples, seu posicionamento estratégico atual e definam qual a posição que desejam ocupar. Além disso, considerando-se que todo o posicionamento é relativo, o modelo ECP-Ambiental induz as empresas a estabelecerem comparações com os seus principais competidores, ou entre unidades de negócios distintas na mesma empresa.

\section{Agradecimentos}


- Ao apoio financeiro e institucional do Serviço Nacional de Aprendizagem Industrial - SENAI

- Ao apoio financeiro do Conselho Nacional de Desenvolvimento Científico e Tecnológico- CNPq

\section{Referências Bibliográficas}

ABREU, Mônica Cavalcanti Sá de. Modelo de Avaliação da Estratégia Ambiental: Uma Ferramenta para Tomada de Decisão. Tese (Doutorado em Engenharia de Produção) - Programa de Pós-Graduação em Engenharia de Produção, Universidade Federal de Santa Catarina, Florianópolis, 2001.

ABREU, Mônica, C.S., FIGUEIRÊDO, Hugo, S. Junior; VARVAKIS, Gregório. Modelo de Avaliação da Estratégia Ambiental: Os Perfis de Conduta Estratégica. Gestão Ambiental e Competitividade na Empresa. READ Edição Especial 30, vol 8, nº.6, dezembro de 2002.

ABREU, Mônica Cavalcanti Sá, VARVAKIS, Gregório e FIGUEIREDO Jr, Hugo Santana. As Pressões Ambientais na Estrutura da Indústria, RAE-Eletrônica. v.3, n.2, Art.17, Jul.Dez./2004.

ANÁLISE SETORIAL: Fiação, Tecelagem, Malharia. São Paulo: GAZETA MERCANTIL S. A, 1999. (Panorama Setorial, V. I e V. III) ASSOCIAÇÃO BRASILEIRA DE NORMAS TÉCNICAS - ABNT. Sistemas de Gestão Ambiental - Especificações e diretrizes para uso: NBR ISO 14001. São Paulo : ABNT, out. 1996.

ASSOCIAÇÃO BRASILEIRA DA INDÚSTRIA QUÍMICA - ABIQUIM. Atuação Responsável. Disponível em <URL: http://abiquim.com.html> Acesso em: [12/11/2001].

BANCO NACIONAL DE DESENVOLVIMENTO ECONÔMICO E SOCIAL, Serviço Brasileiro de Apoio às Micro e Pequenas Empresas; Confederação Nacional da Indústria. Pesquisa Gestão Ambiental na Indústria. Rio de Janeiro: BNDES; Brasília: CNI, SEBRAE, 71 p. 1998.

BANCO DO NORDESTE. Manual de Impactos Ambientais: orientações básicas de aspectos ambientais de atividades produtivas. Equipe de elaboração Marilza do Carmo Oliveira Dias (coordenadora), Fortaleza: Banco do Nordeste, 297p. 1999

DELMAS, Magali, Toffel Michael W. Stakeholders and Environmental Management Practices: An Institutional Framework. Business Strategy and the Environment. 13, p.209-222, 2004

ELKINGTON, Jonh. Petroleum in the 21st century: The triple bottom line: implications for the oil industry. Oil \&t Gas, v. 97, n. 50, dez. 1999.

ELKINGTON, Jonh. Cannibals with Forks: The triple bottom line of 21 st century business. Canada: NSP, 1998.

ELKINGTON, John, TRISOGLIO, Alex. Developing Realistic Scenarios for Environment: Lessons from Brent Spar. Long Range Planning. v.29, n.6, p 762-769, 1996.

JOSE, P.D. Corporate Strategy and the Environment: a Portfolio Approach. Long Range Planning, 29: 462-472, 1996

MAIMON, Dalia. Passaporte Verde: Gerência Ambiental e Competitividade. Rio de Janeiro: Qualitymark, 1996.

MURRAY, Jones G., HARTOG Jan J., SKYES, Richard M. Environmental performance indicators - The line and management tool. Conf Health Safety Envir Oil Gas Explor Prod, Society of Petroleum Engineers (SPE), Richardson, TX, (USA), v. 2, p.537-545, 1996.

NORCIA, Vicent di. Environmental and Social Performance. Journal of Business Ethics, v.15, n. 7, pp. 773-784, 1996.

ORGANISATION FOR ECONOMIC CO-OPERATION AND DEVELOPMENT - OECD. Towards Sustainable Development: Environmental Indicators. Paris : OECD, 1998.

PORTER, Michael E. Competição. On Competition: Estratégias Competitivas Essenciais. Rio de Janeiro: Campus, 1999 PORTER, Michael. E. Competitive Strategy. New York: The Free Press, 1980 
POST, J. E.; Altman, B. W.. Managing the Environmental Change Process: Barries and Opportunities. Journal of Organizational Change Management, 7: 64-81,1994.

RYE, H.; CELIUS, H.; HUSDAL, G.; GUTTORMSEN, R. 1997. Environmental Indicators Applied to the Norwegian Oil and Gas Industry. SPE/UJKOOA European Environmental Conference in Aberdeen, Scotland, April, SPE paper No. 37849.

RODRIGUEZ, Miguel Ángel; RICART, Joan Enric. Dirección Medioambiental de la Empresa. Barcelona : Gestión 2000, 1998.

SCHERER, F. M.; ROSS, David. Industrial Market Structure and Economic Performance. 3. Ed. Boston : Houghton Mifflin, 1990.

SERVIÇO NACIONAL DE APRENDIZAgEM INDUSTRIAL - Departamento Regional do Ceará - SENAI-CE. Indústria Cearense: Perfil Ambiental e Demanda por Serviços. Pesquisa de Mercado, 1997. 